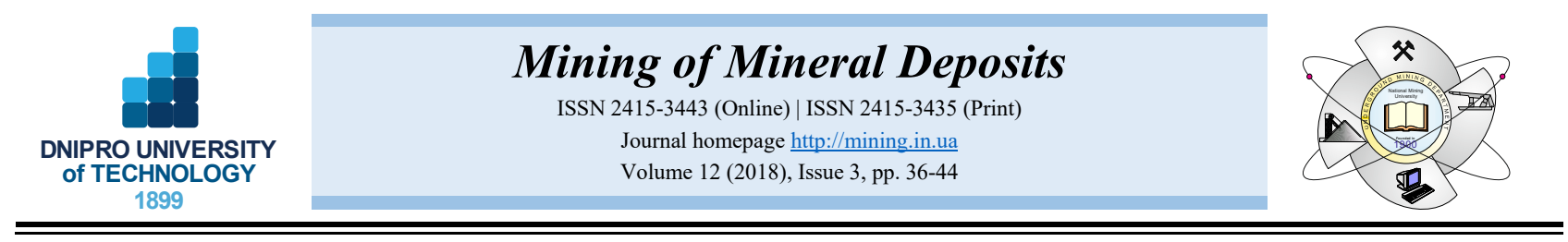

UDC 622.734

https://doi.org/10.15407/mining12.03.036

\title{
ESTIMATION OF THE WEAR RATE ASSOCIATED WITH BALL MILL OF MAHD AD DAHAB GOLD MINE, SAUDI ARABIA (KSA)
}

\author{
G.S. Abdelhaffez ${ }^{1,2^{*}}$ \\ ${ }^{1}$ University of Assiut, Assiut, Egypt \\ ${ }^{2}$ King Abdulaziz University, Jeddah, Saudi Arabia \\ *Corresponding author: e-mail gamalhaffez@gmail.com, tel.+966544166062
}

\begin{abstract}
Purpose. This study aims to estimate the wear of the middle chrome grinding balls in both dry and wet grinding media. The selected ball mill for this study is located at Mahd Ad Dahab Gold Mine, Saudi Arabia.

Methods. The amount of wear is determined based on the decrease in the balls weight with respect to grinding time.

Findings. The results show that, the loss in the balls weight is proportionally related to their diameters. Also, the amount of wear is reduced by almost $12 \%$ when using wet grinding than dry medium.

Originality. This study provides a methodology to evaluate the performance efficiency of grinding operation as a function of the amount of wear results in the grinding medium.

Practical implications. Grinding is an intrinsic step in almost all mineral processing. Such step is very expensive; but, it is essentially required to reduce the size of the run-of-mine (ROM) material, to liberate valuable minerals from the ore matrix and to increase the surface area for higher reactivity. Thus, this study sheds light on the cost of wear rate associated with ball mill at Mahd Ad Dahab Gold Mine, Saudi Arabia, and its significant impact on the efficiency of grinding operation.
\end{abstract}

Keywords: grinding process, wet and dry grinding media, wear, ball mill, Mahd Ad Dahab Mine

\section{INTRODUCTION}

Comminution is an indispensable process of mineral processing and circuits of size reduction consume huge amounts of energy (Stamboliadis, 2002). Such process is employed in various fields including mineral processing, power plants, cement production, steel, ceramic and glass industries, cosmetics products and pharmaceutical industries. In mineral processing, it is basically applied to liberate valuable minerals from the host rock and facilitate their transportation for subsequent operations. In power plants, coal is ground to increase fineness and surface area of its particles (Lameck, 2005; Kapakyulu, 2007; Lucy, 2016). Used balls in milling operations are responsible for the most of the consumable costs. They form 40 to $45 \%$ of the comminution total costs (Moema, Papo, Slabbert, \& Zimba, 2009). As an example, a typical copper processing plant, which produces about 100000 tons/day, spends approximately $\$ 25000$ /day to replace the consumed grinding medium in ball milling. Likewise, the iron industry consumed 708000 tons of grinding media to produce pellets in 1978 (Tolley, Nichols, \& Huiatt, 1984).
Comminution is considered an energy-devoured process and inefficient-consumer of grinding media. (Fuerstenau, Lutch, \& De, 1999) reported that, comminution consumes up to $70 \%$ of the total energy required in a typical mineral processing plant. In 1976 , over $3 \%$ of the worldwide electrical energy has been consumed in comminution operations (e.g. crushing and grinding) (Fuerstenau \& Abouzeid, 2002). In 2001, up to $1.5 \%$ of the national Australian energy has been consumed in comminution; in 2003, about $1.8 \%$ of the total energy has been used in comminution operations in South Africa (Djordjevic, 2010; Wang, 2013). In 2007, US Department of Energy reported that, comminution consumed about $50 \%$ of the total mining energy in the United States (U.S. DOE, 2007), as depicted in Figure 1. Also, it has been reported that approximately $50 \%$ of comminution operation costs are due energy consumption, while the other half is attributed to liner/charge wear (Radziszewski, 2002; Massola, Chaves, \& Albertin, 2016). On other meaning, the total costs of comminution are equally divided between energy consumption and replacement of worn grinding media. 


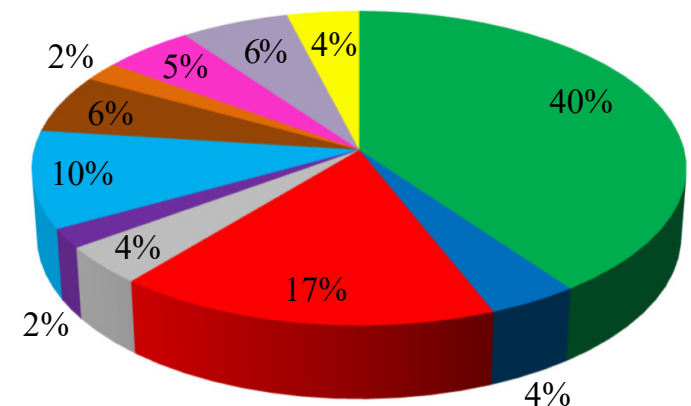

$\begin{array}{ll}\square \text { Grinding } & \square \text { Crushing } \\ \square \text { Material handling-diesel } & \text { Separation } \\ \square \text { Dewatering } & \text { Ventilation } \\ \square \text { Digging } & \text { Blasting } \\ \text { Material handling- } & \text { Ancillary operations } \\ \text { electric equipments } & \text { Drilling }\end{array}$

Figure 1. Energy consumption in mining industry, USA (U.S. DOE, 2007; Wang, 2013)

The cost of comminution will arise in non-linear fashion particularly, when the ore extremely varies in size and contains large quantities of fineness (Howat \& Vermeulen, 1986a; Howat \& Vermeulen, 1986b; Kapakyulu, 2007). The efficiency of grinding process is affected by several factors including characteristics of grinding medium (e.g. metallographic composition, hardness, size and shape), ore/rock properties (e.g. strength, size), milling parameters (e.g. feed size, speed) (Howat \& Vermeulen, 1988). Wear has significant impact on the performance of comminution process and by turn, on the total costs of comminution. Thus, it will be presented in the next section.

\section{WEAR IN COMMINUTION PROCESS}

The major concern in comminution process is the wear of grinding media. The cost of milling operations dramatically increases due to high consumption of balls in the fine grinding of ores. Alternatively, the consumption of grinding media (e.g. balls) is the prominent item that raises the milling operation costs (Vermeulen, Howat, \& Gough, 1983). As an example, the annual global consumption of steel alone exceeds 600000 tonnes (Massola, Chaves, \& Albertin, 2016). Therefore, reduction of the wear is necessary to reduce the total operating costs and increase profitability (Tolfree, 2004). A wide variety of grinding balls is existed by manufacturers, but selecting appropriate grinding medium (e.g. related to durability and cost-effective balls) is difficult especially for grin-ding ore under certain milling conditions. Thus, full metallurgical characterization (e.g. chemical analysis, hardness profile, and microstructure) has to be conducted to select the suitable cost-effective grinding balls (Pitt, Chang, Wadsworth, \& Kotlyar, 1988; Moema, Papo, Slabbert, \& Zimba, 2009). The grinding medium should provide maximum performance, minimum wear rate and highest grinding transfer to cost ratio (Jankovic, Wills, \& Dikmen, 2016). It is important to predict the rate of mill wear to obtain close estimate of its cost. Wear prediction provides closer insight about the replacement cost of grinding media, the size distribution of the grinding medium in the mill and grinding behavior in the mill (Azizi, 2015).

\subsection{Wear mechanism}

As the medium consumption contributes significantly to the total milling cost, great effort has been expended in the study of medium wear. Three wear mechanisms are generally recognized: abrasion, corrosion, and impact (Rajagopal \& Iwasaki, 1992). Abrasion refers to the direct removal of metal from the grinding media surface. While, corrosion defines less resistance corrosion product films has been abraded away during wet grinding (Gangopadhyay \& Moore, 1985a; Gangopadhyay \& Moore, 1985b; Meulendyke \& Purdue, 1989; Wills \& Napier-Munn, 2006). The latter, impact mechanism, refers to spalling, pitting, flaking and/or breaking occurred in the ore-metalenvironment contact (Misra \& Finnie, 1980; Gangopadhyay \& Moore, 1987). Several studies reveal that abrasion is the dominant cause of wear (e.g. metal loss) in grinding process, while corrosion accounts for less than $10 \%$ of the total loss (Dodd, Dunn, Huiatt, \& Norman, 1985). However, it is difficult to separate the contribution of each wear mechanism (Radziszewski, 2000; Ajaal, Smith, \& Yen, 2002). Many attempts have been recently conducted to predict the wear of grinding media by developing a total media wear model incorporating the three wear mechanisms (e.g. abrasive, corrosive, and impact) (Radziszewski, 2002). The parameters of the developed model have been determined based on ore-metalenvironmental interaction. The results are then being confirmed with full-scale grinding operation data obtained from laboratory tests. The next section will discuss the critical factors influencing the wear of grinding media.

\subsection{Factors affecting grinding ball wear}

Grinding is usually performed wet, however in some applications dry grinding is applied. The wear results in wet grinding due to abrasion, is much higher that occurred in dry grinding environment (Moore, Perez, Gangopadhyay, \& Eggert, 1988; Mishra \& Rajamani, 1994). The consumption of balls forms a dominant proportion of the total costs of grinding process. Understanding the factors influencing the ball wear is necessary to reduce such consumption. Figure 2 depicts the wear type and the crucial factors affecting the ball wear.

Such wear depends on the type of grinding media, media size, mill parameters (e.g. size, speed), properties of rock/ore being ground (e.g. particles shape and size), machine operating conditions (e.g. feed rate, density of pulp), liner type, volume of charge, manufacture quality and environmental parameters (e.g. moisture and temperature) (Chen je, 2007; Härkisaari, 2015). Table 1 summarizes the impact of significant factors on the wear rate.

\subsection{Wear measurement}

The wear of ball mill can be measured using direct and indirect methods. These two methods are briefly discussed in the following section.

\subsubsection{Indirect wear test}

Bond abrasion index test is used to measure energy consumption and its corresponding wear rates of grinding media. Such abrasion test is dating back to 1952 (Weiss, 1985) and is still used to estimate the total mill media wear. Indirect wear test is a purely empirical and is solely based on the ore properties. 


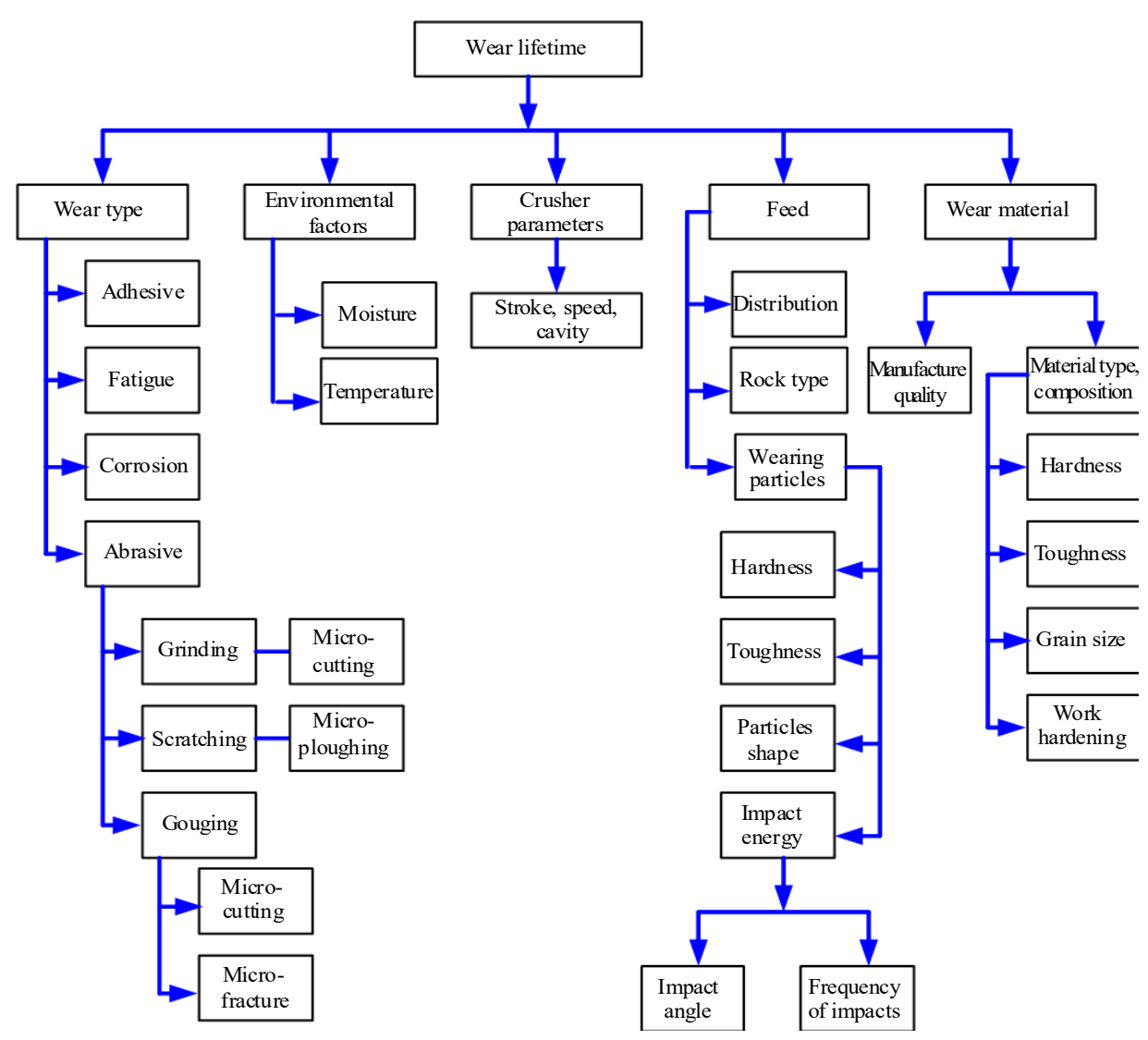

Figure 2. Factors influencing wear lifetime (Härkisaari, 2015)

Table 1. Milling parameters affecting grinding ball wear (Yelloji Rao \& Nararajan, 1991)

\begin{tabular}{|c|c|c|}
\hline Milling parameters & Trend & Type of effect \\
\hline $\begin{array}{l}\text { 1. Grinding charge } \\
\text { - grinding media size } \\
\text { - grinding media distribution }\end{array}$ & $\begin{array}{c}\text { increase size } \\
\text { increase small size } \\
\text { increase charge weight }\end{array}$ & $\begin{array}{l}\text { decrease wear rate } \\
\text { increase wear rate } \\
\text { increase wear rate }\end{array}$ \\
\hline $\begin{array}{l}\text { 2. Ore } \\
\text { - work index } \\
\text { - hardness } \\
\text { - density } \\
\text { - grade/concentration }\end{array}$ & $\begin{array}{c}\text { increase work index } \\
\text { increase hardness } \\
\text { increase density } \\
\text { increase grade/concentration }\end{array}$ & $\begin{array}{l}\text { increase wear } \\
\text { increase wear } \\
\text { increase wear } \\
\text { increase wear }\end{array}$ \\
\hline 3. Abrasion nature of gangue & increase silica content & increase wear \\
\hline $\begin{array}{l}\text { 4. Particles } \\
\text { - feed size } \\
\text { - product size } \\
\text { - shape }\end{array}$ & $\begin{array}{l}\text { increase size } \\
\text { increase size } \\
\text { sharp corners }\end{array}$ & $\begin{array}{l}\text { increase wear } \\
\text { decrease wear } \\
\text { increase wear }\end{array}$ \\
\hline $\begin{array}{l}\text { 5. Slurry } \\
\text { - corrosion } \\
\text { - viscosity } \\
\text { - } \% \text { solids }\end{array}$ & $\begin{array}{c}\text { decrease } \mathrm{pH} \\
\text { increase viscosity } \\
\text { decrease } \% \text { solids }\end{array}$ & $\begin{array}{l}\text { increase wear } \\
\text { decrease wear } \\
\text { increase wear }\end{array}$ \\
\hline $\begin{array}{l}\text { 6. Nature of Contact } \\
\text { - impact velocity } \\
\text { - impact angle }\end{array}$ & $\begin{array}{l}\text { increase velocity } \\
\text { increase angle }\end{array}$ & $\begin{array}{l}\text { increase wear } \\
\text { increase wear }\end{array}$ \\
\hline $\begin{array}{l}\text { 7. Mill } \\
\text { - discharge type } \\
\text { - diameter } \\
\text { - speed }\end{array}$ & $\begin{array}{c}\text { overflow } \\
\text { increase diameter } \\
\text { increase speed }\end{array}$ & $\begin{array}{l}\text { increase wear } \\
\text { increase wear } \\
\text { increase wear }\end{array}$ \\
\hline $\begin{array}{l}\text { 8. Circuit } \\
\text { - throughput } \\
\text { - circulating load }\end{array}$ & $\begin{array}{c}\text { increase throughput } \\
\text { increase circulating load }\end{array}$ & $\begin{array}{l}\text { decrease wear } \\
\text { increase wear }\end{array}$ \\
\hline $\begin{array}{l}\text { 9. Grinding media quality } \\
\text { - hardness (surface/avg. volumetric) } \\
\text { - grain size } \\
\text { - carbon content } \\
\text { - alloy contents } \\
\text { - shape }\end{array}$ & $\begin{array}{l}\text { increase hardness } \\
\text { increase grain size } \\
\text { increase carbon content } \\
\text { increase alloy contents } \\
\text { sphere }\end{array}$ & $\begin{array}{l}\text { decrease wear } \\
\text { increase wear } \\
\text { decrease wear } \\
\text { decrease wear } \\
\text { minimum wear }\end{array}$ \\
\hline
\end{tabular}


The test gives an index value, which is then incorporated in a formula to determine the metal wear rate expressed as weight of metal worn per energy consumed in comminution process, $(\mathrm{kg} / \mathrm{kWh})$. This test measures the weight loss of a metal (e.g. steel paddle) which continuously impacts falling ore particles for 60 minutes under a standardized testing condition (Jankovic, Wills, \& Dikmen, 2016). From Bond abrasion index tests, it is possible to determine a wear rate using the following empirical equation (1) (Chen je, 2007):

$$
\frac{\text { Wear }}{\text { Energy }}=0.159\left(A_{i}-0.015\right)^{0.33}, \mathrm{~kg} / \mathrm{kWh} \text {, }
$$

where:

$$
A_{i}-\text { the Bond abrasion index. }
$$

\subsubsection{Direct wear test}

It is also known as Marked Ball Wear Test (MBWT). The test is used to measure the wear of grinding media resulted from corrosion in relation to mill $\mathrm{pH}$ (Moema, Papo, Slabbert, \& Zimba, 2009). Alternatively, the direct wear test is applied to measure the performance of grinding media (e.g. wear rate) under certain conditions (e.g. slurry properties). Experimental investigations reveal that, corrosion accounts for $13-20 \%$ of the wear of grinding media.

In this study, the wear of ball mill is determined in both wet and dry grinding medium. The loss of balls weight is calculated with respect to grinding time. The case study used for this investigation is the Mahd Ad Dahab gold mine, Saudi Arabia.

\section{EXPERIMENTAL WORK}

The work is conducted at the Department of Mining Engineering, King Abdul-Aziz University, KSA. The Mineral processing lab facility and equipments have been used to carry out this study, as introduced in the following section.

\subsection{Material and equipment used}

In this study, samples of quartz are collected from Mahd Ad Dahab Gold Mine. The mine is located approximately $380 \mathrm{~km}$ North-East of Jeddah, Saudi Arabia. The collected samples are free from any apparent defects, as shown in Figure 3.

The veins of quartz contain base metal sulphides (e.g. oxide derivatives close to surface), native gold and gold silver tellurides. Also, rocks comprise of a series of tonalitic and granodiorite batholiths associated with volcano-sedimentary rocks.

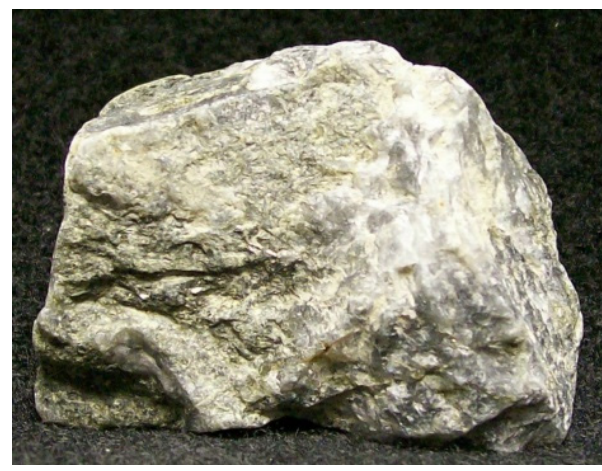

Figure 3. Lump quartz sample collected from Mahd Ad Dahab Gold Mine, KSA

\subsubsection{Ground ore}

Laboratory jaw crusher has been used to reduce the size of run-of-mine rock samples to $-3.15 \mathrm{~mm}$ in order to be suitable for subsequent ball mill. The size of crushed samples is screened to obtain $-3.15+2.5 \mathrm{~mm}$ which is appropriate for the dimensions of mill and grinding media.

\subsubsection{Grinding medium}

Figure 4 shows middle chrome grinding balls which have been used in grinding process. Ball concentration is 4 to $6 \%$ and its hardness $\geq 48$ HRC (e.g. rockwell hardness scale). The performance of chrome balls is better comparing with that made from alloy.

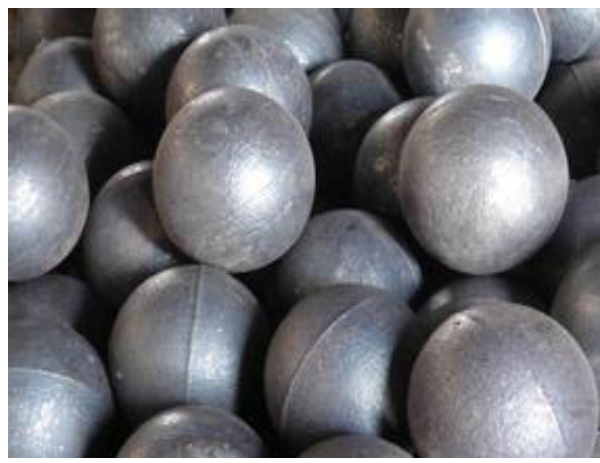

Figure 4. Middle chrome casting

The chemical composition of the middle chrome casting steel balls is given in Table 2 .

\subsubsection{Lining ball mill}

Ball mill used in this study is depicted in Figure 5. It comprises of a drum which is made from welded steel of dimensions of $300 \mathrm{~mm}$ (e.g. inside diameter) by $300 \mathrm{~mm}$ (e.g. length). In addition, a cylindrical shell that rotates on a horizontal axis.

Table 2. Chemical composition of the middle chrome casting steel

\begin{tabular}{cccccccccc}
\hline \multirow{2}{*}{$\begin{array}{c}\text { Chemical } \\
\text { composition, } \\
\%\end{array}$} & $\begin{array}{c}\text { Carbon, } \\
\mathrm{C}\end{array}$ & $\begin{array}{c}\text { Silica, } \\
\mathrm{Si}\end{array}$ & $\begin{array}{c}\text { Manganese, } \\
\mathrm{Mn}\end{array}$ & $\begin{array}{c}\text { Chrome, } \\
\mathrm{Cr}\end{array}$ & $\begin{array}{c}\text { Copper, } \\
\mathrm{Cu}\end{array}$ & $\begin{array}{c}\text { Molybdenum, } \\
\mathrm{Mo}\end{array}$ & $\begin{array}{c}\text { Phosphorous, } \\
\mathrm{P}\end{array}$ & $\begin{array}{c}\text { Sulfur, } \\
\mathrm{S}\end{array}$ & $\begin{array}{c}\text { Iron, } \\
\mathrm{Fe}\end{array}$ \\
\cline { 2 - 10 } & $2.1-3.6$ & $\leq 1.5$ & $0.3-1.5$ & $4.0-6.0$ & $\leq 0.8$ & $\leq 1.0$ & $\leq 0.1$ & $\leq 0.1$ & $\begin{array}{c}\text { Balanced } \\
\text { to } 100 \%\end{array}$ \\
\hline
\end{tabular}

The shell of the ball mill is designed to withstand the rotational load of the mill which is charged with the grinding medium and the material to be processed. Grinding medium and rock/ore are loaded and discharged through openings. The mill is driven by motor which is coupled to the Reduction Gear box with Chain and Sprocket arrangement. Ball mill is lined with rubber and resistant metallic liners. 


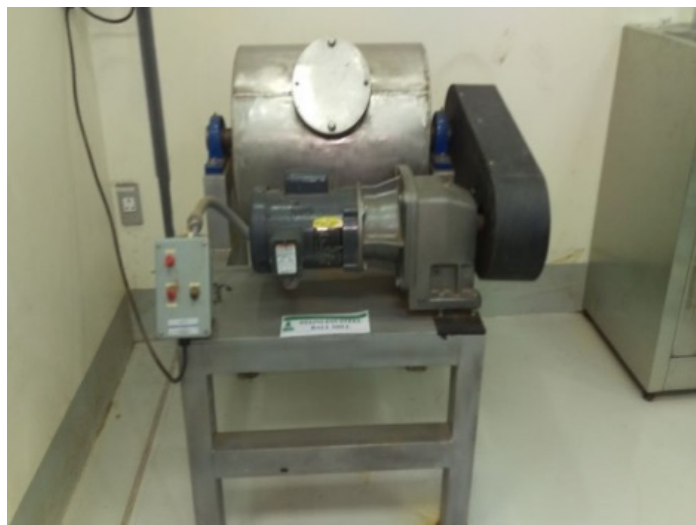

Figure 5. Ball mill layout used in laboratory experiments

Mills may be charged with steel or alloy steel grinding media of spherical shape and ranged from 6 to $60 \mathrm{~mm}$ in size. The capacity of the mill is about 2 to $10 \mathrm{~kg}$ of ground ore.

\subsubsection{Digital balance}

The grinding ball mills are weighted before and after each test using digital scale. Herein, Shimadzu BX-32 digital balance, unit in grams $(\mathrm{g})$, is used. Balance capacity is $32 \mathrm{~kg}$ with accuracy of $0.1 \mathrm{gm}$. The balance response time is about 2 to $2.5 \mathrm{sec}$ and the ambient temperature $5-40^{\circ} \mathrm{C}$.

\subsection{Experimental procedures}

In this article, the mill ball wear is examined in both wet and dry grinding process for Mahd Ad Dahab Gold Mine ore. Lab ball mill is used for this study and its operating conditions are set with the aid of the work done by Rizk (1989) and Abdelhaffez (2005). Such conditions are kept constant for all experiments and summarized as follows:

- the occupied volume with the charge is $40 \%$ of the total mill volume;

- the mill operating speed equals $80 \%$ of critical speed;

- the diameters of grinding media (e.g. medium chrome casting steel balls) are 20 and $30 \mathrm{~mm}$;

- interstitial filling of voids between balls by ground material is $85 \%$;

- in wet grinding the percentage of water is $15 \%$ from the total internal volume of the mill.

In dry grinding operation, $100 \%$ of mill balls of diameter $20 \mathrm{~mm}$ and $100 \%$ of balls of diameter of $30 \mathrm{~mm}$ are used. In addition, mixed ball load which composed of $50 \%$ balls of $20 \mathrm{~mm}$ diameter and $50 \%$ balls of $30 \mathrm{~mm}$ diameter are also applied. In wet grinding process, the same percentages of balls diameters as in dry grinding conditions plus $15 \%$ of water from the total internal volume of ball mill. The grinding time is crucial parameter in grinding operation. Various grinding times are set (e.g. 4, 8, 16, 24, 48, 72 and $96 \mathrm{hr}$ ). All charge of ball media is weighted in digital balance before and after each test. After each run all charge passed through $-3.15 \mathrm{~mm}$ screen apparatus to retain the ball media, and then the ball media is well cleaned by light Hydrochloric acid to remove any contaminations. The ball wear (BW) is calculated by the subtracting the balls weight (e.g. after each test) from the initial balls weight (e.g. before conducting the test). Mathematically, ball wear can be estimated from the following equation:

$$
\text { Ball wear }=\frac{\text { Weight of ball loos or weight of wear }}{\text { Initial ball weight }} \cdot 100 \text {. }
$$

\section{RESULTS AND DISCUSSION}

In the following section, a brief introduction to ball mill which is used in this investigation followed by experimental results.

\subsection{Tumbling mill of Mahd Ad Dahab Gold Mine, KSA}

In Mahd Ad Dahab Mine, the run-of-mine (ROM) ore is directly loaded from underground to crusher. Wherein, the ROM ore is crushed into three stages to reduce its size to $10 \mathrm{~mm}$. The crushed ore (e.g. of $10 \mathrm{~mm}$ size) is then conveyed to blending stockpile. The blended ore is then reclaimed and fed to ball mill at a rate of 24.5 wet ton/hour to obtain $80 \%$ passing at 74 micron size. Grinding is the final stage in comminution process, where the size of ore particles is reduced by hybrid effect of impact and abrasion. The operating parameters of Mahd Ad Dahab tumbling mill are listed in Table 3. While, Table 4 lists the mechanical characteristics of Mahd Ad Dahab tumbling mill.

Table 3. Operating parameters of Mahd Ad Dahab tumbling mill

\begin{tabular}{lc}
\hline \multicolumn{1}{c}{ Feed } & Gold-bearing quartzite \\
\hline Feed rate, $\mathrm{t} / \mathrm{h}$ & New feed 21 \\
Feed size $\mathrm{mm}$ & $100 \%$ minus $100 \mathrm{~mm}$ \\
Product size, $\mathrm{mm}$ & $80 \%$ minus $0.074 \mathrm{~mm}$ \\
Grinding & Closed circuit type with hydro cyclones \\
Actual speed, rpm & 17 \\
Bond work index, & 21.8 \\
$\mathrm{kWh} / \mathrm{mt}$ & \\
\hline
\end{tabular}

Table 4. Mechanical characteristics of Mahd Ad Dahab tumbling mill

Inside shell diameter, $\mathrm{mm} \quad 3.20$

Shell length, mm $\quad 4.00$

Speed, rpm

16.85

Maximum ball charge

Ball diameter, $\mathrm{mm}$

Critical speed, rpm $84.0 \mathrm{~kg}=40 \%$ by volume 60 to 25 23

Power requirement at max

ball charge, $\mathrm{kw}$

Installed motor

The capacity of the tumbling mill of Mahd Ad Dahab Mine is 500 ton/hour with $80 \%$ minus $0.074 \mathrm{~mm}$ size product. At steady state, about $85000 \mathrm{~kg}$ of steel balls is charged into tumbling mill in addition to daily new feed rate (e.g. $1000 \mathrm{~kg}$ /day) of the steel balls of size $60 \mathrm{~mm}$ diameter. This means that, the daily rate of ball wear is $1.2 \%$.

This study sheds the lights on the effect of some parameters (e.g. characteristics of grinding media and grinding time) on the performance of grinding process in terms of ball wear rate. Such analyses might be helpful when they are applied in commercial practice (e.g. industry). But, these analyses should be evaluated based on exact mill operating conditions to estimate their cost-effectiveness. 


\subsection{Experimental results}

The rate of ball wear is calculated using Equation (2) which has been mentioned beforehand. Table 5 lists the values of the ball wear in dry and wet grinding media and at various ball diameters. Figure 6 displays the effect of grinding time and ball diameter on the rate of ball wear in both dry and grinding operations. The results reveal that, the rate of ball wear significantly increases as grinding time increases. Also, the ball diameter is proportional to the rate of ball wear. Alternatively, the rate of ball wear sharply increases with the increase of ball diameter. Such increase may be attributed to that; the rate of ball wear during abrasive processes is proportional to the surface area of the balls. In addition, the rates of ball wear obviously increases in dry grinding medium than in wet medium. In dry grinding process, high resistance of the chrome balls may be existed. Therefore, it will accelerate the abrasion and corrosion of balls particularly in the presence of oxygen. On contrary, the presence of water will eventually minimize friction among balls. Thus, less abrasion will be existed and consequently, less ball wear rate is resulted.

Table 5. Rates of ball wear at various grinding times and different ball diameters in both dry and wet grinding media

\begin{tabular}{|c|c|c|c|c|c|c|}
\hline \multirow{4}{*}{$\begin{array}{l}\text { Grinding } \\
\text { time, hrs }\end{array}$} & \multicolumn{3}{|c|}{ Dry grinding medium } & \multicolumn{3}{|c|}{ Wet grinding medium } \\
\hline & \multicolumn{3}{|c|}{ Ball diameters } & \multicolumn{3}{|c|}{ Ball diameters } \\
\hline & $20 \mathrm{~mm}$ & $30 \mathrm{~mm}$ & $\begin{array}{c}\text { Mixed balls } \\
(50 \% \text { of } 20 \mathrm{~mm} \\
\text { and } 50 \% \text { of } 30 \mathrm{~mm})\end{array}$ & $20 \mathrm{~mm}$ & $30 \mathrm{~mm}$ & $\begin{array}{c}\text { Mixed balls } \\
(50 \% \text { of } 20 \mathrm{~mm} \\
\text { and } 50 \% \text { of } 30 \mathrm{~mm})\end{array}$ \\
\hline & \multicolumn{3}{|c|}{ Ball wear rate, $\%$} & \multicolumn{3}{|c|}{ Ball wear rate, $\%$} \\
\hline 4 & 0.123 & 0.140 & 0.131 & 0.107 & 0.124 & 0.114 \\
\hline 8 & 0.160 & 0.185 & 0.175 & 0.140 & 0.163 & 0.152 \\
\hline 16 & 0.222 & 0.257 & 0.245 & 0.194 & 0.226 & 0.213 \\
\hline 24 & 0.280 & 0.326 & 0.301 & 0.245 & 0.285 & 0.261 \\
\hline 48 & 0.385 & 0.447 & 0.431 & 0.338 & 0.394 & 0.372 \\
\hline 72 & 0.541 & 0.626 & 0.592 & 0.473 & 0.551 & 0.513 \\
\hline 96 & 0.739 & 0.858 & 0.791 & 0.647 & 0.754 & 0.687 \\
\hline
\end{tabular}

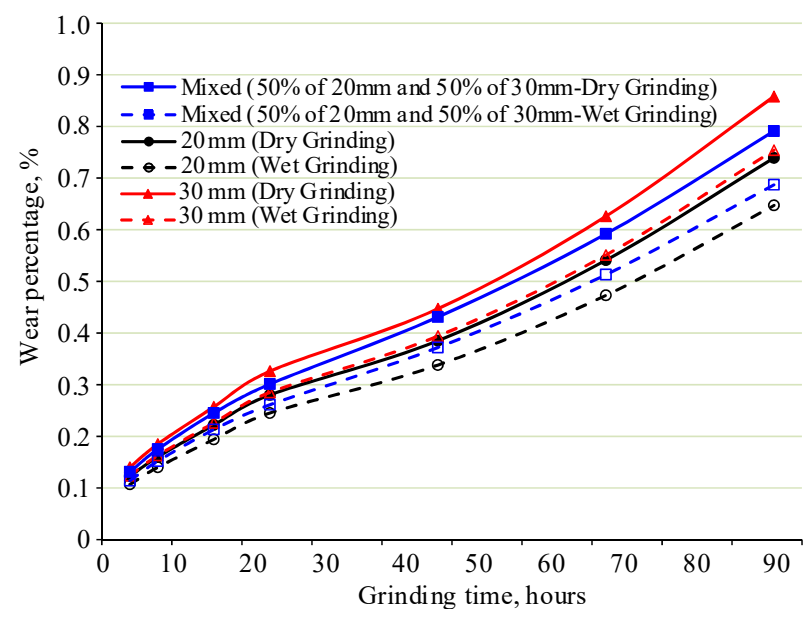

Figure 6. Percentage of ball wear rates at various grinding times and different ball diameters in both dry and wet grinding media

It is noteworthy to mention that, the ball type and the wear produced due to the effect of lining are not considered in this study. Thus, this study shows that, the ball wear rate is not exceeding $0.3 \%$ per day.

Also, it is noticed that, the work conducted in the laboratory shows that, the ball wear rate after four hours of grinding process is higher than that after four days (e.g. 96 hours). This might relate to ore fineness which acts as an abrasive during prolonged grinding operation. Liners in a ball mill play crucial role in protecting the interior mill shell from the impact and the wear, while transferring energy to optimize grinding efficiency. These conflicting requirements mean that the lining must be carefully designed to ensure optimum, long-lasting performance and to reduce load stress on the mill.

\section{CONCLUSIONS}

Wear is crucial concern in grinding process. The efficiency of grinding operation is judged based on wear cost. Numerous studies have been conducted to reduce the costs associated with comminution. Various metals, non-metals, and different shapes of grinding media have been attempted. Among all this, steel grinding balls have found to be the most effective grinding media for comminution in tumbling mills. The objective of this study is to estimate the ball wear rate, in both dry and wet grinding media, at various grinding time using different ball sizes. The results show that, the ball wear rate significantly increases as the grinding time increases. As well, the wear rate is proportional to ball diameter. Also, the study reveals that, the ball wear rate in wet grinding medium is smaller than that resulted in dry medium. Alternatively, the highest ball wear rate (e.g. $0.858 \%$ ) is obtained at longest grinding time (e.g. 96 hours), biggest ball diameter (e.g. $30 \mathrm{~mm}$ ) and in dry grinding medium. In Mahd Ad Dahab Gold Mine, the ball wear rate is about $1.2 \%$ per day; however, this rate is about $0.3 \%$ per day in laboratory tests as ball mill is laminated by rubber layer.

\section{RECOMMENDATION FOR FUTURE WORK}

Parametric analysis is recommended to examine the impact of lining, different ball types, feed rate, grinding speed, $\mathrm{pH}$ of slurry and solid percent in the pulp, on the ball wear rate.

\section{ACKNOWLEDGEMENTS}

The author acknowledges the support of Mahd Ad Dahab Gold Mine (Metallurgical section), Saudi Arabia (KSA) for getting technical data used in this study. The author is grateful for their endless support and sincere cooperation. 


\section{REFERENCES}

Abdelhaffez, G. (2005). Assessment of energy efficiency in grinding process. PhD Thesis. Assiut, Egypt: Assiut University.

Ajaal, T., Smith, R.W., \& Yen, W.T. (2002). The development and characterization of a ball mill for mechanical alloying. Canadian Metallurgical Quarterly, 41(1), 7-14.

https://doi.org/10.1179/cmq.2002.41.1.7

Azizi, A. (2015). Investigating the controllable factors influencing the weight loss of grinding ball using SEM/EDX analysis and RSM model. Engineering Science and Technology, an International Journal, 18(2), 278-285. https://doi.org/10.1016/j.jestch.2014.12.007

Chen je, W.T. (2007). Development and validation of a model for steel grinding media wear in tumbling mills. $\mathrm{PhD}$ Thesis. Montreal, Canada: McGill University.

Djordjevic, N. (2010). Improvement of energy efficiency of rock comminution through reduction of thermal losses. Minerals Engineering, 23(15), 1237-1244. https://doi.org/10.1016/j.mineng.2010.08.019

Dodd, J., Dunn, D.J., Huiatt, J.L., \& Norman, T.E. (1985). Relative importance of abrasion and corrosion in metal loss in ball milling. Minerals and Metallurgical Processing, 2(4), 212-216.

Fuerstenau, D.W., Lutch, J.J., \& De, A. (1999). The effect of ball size on the energy efficiency of hybrid high-pressure roll mill/ball mill grinding. Powder Technology, 105(1-3), 199-204.

https://oi.org/10.1016/s0032-5910(99)00138-2

Fuerstenau, D., \& Abouzeid, A.-Z. (2002). The energy efficiency of ball milling in comminution. International Journal of Mineral Processing, 67(1-4), 161-185. https://doi.org/10.1016/s0301-7516(02)00039-x

Gangopadhyay, A.K., \& Moore, J.J. (1985a). Assessment of wear mechanisms in grinding media. Minerals and Metallurgical Processing, 2(3), 145-151.

Gangopadhyay, A.K., \& Moore, J.J. (1985b). The role of abrasion and corrosion in grinding media wear. Wear, 104(1), 49-64. https://doi.org/10.1016/0043-1648(85)90245-5

Gangopadhyay, A.K., \& Moore, J.J. (1987). Effect of impact on the grinding media and mill liner in a large semiautogenous mill. Wear, 114(2), 249-260. https://doi.org/10.1016/0043-1648(87)90091-3

Härkisaari, P. (2015). Wear and friction effects on energy consumption in the mining industry. MSc Thesis. Tampere, Finland: Tampere University of Technology.

Howat, D.D., \& Vermeulen, L.A. (1988). Fineness of grind and the consumption and wear rates of metallic grinding media in tumbling mills. Powder Technology, 55(4), 231-240. https://doi.org/10.1016/0032-5910(88)80033-0

Jankovic, A., Wills, T., \& Dikmen, S. (2016). A comparison of wear rates of ball mill grinding media. Journal of Mining and Metallurgy A: Mining, 52(1), 1-10. https://doi.org/10.5937/jmma1601001j

Kapakyulu, E. (2007). Development of a model for temperature in a grinding mill. MSc Thesis. Johannesburg, South Africa: University of the Witwatersrand.

Lameck, N.S. (2005). Effects of grinding media shapes on ball mill performance. MSc Thesis. Johannesburg, South Africa: University of the Witwatersrand.

Lucy, L. (2016). The development and demonstration of a practical methodology for fine particle shape characterisation in minerals processing. PhD Thesis. Cape Town, South Africa: University of Cape Town.

Massola, C.P., Chaves, A.P., \& Albertin, E. (2016). A discussion on the measurement of grinding media wear. Journal of Materials Research and Technology, 5(3), 282-288. https://doi.org/10.1016/j.jmrt.2015.12.003
Meulendyke, M.J., \& Purdue, J.D. (1989). Wear of grinding media in the mineral processing industry: an overview. Minerals and Metallurgical Processing, 6(4), 67-172.

Misra, A., \& Finnie, I. (1980). A classification of three-body abrasive wear and design of a new tester. Wear, 60(1), 111-121. https://doi.org/10.1016/0043-1648(80)90252-5

Mishra, B.K., \& Rajamani, R.K. (1994). Simulation of charge motion in ball mills. Part 1: experimental verifications. International Journal of Mineral Processing, 40(3-4), 171-186. https://doi.org/10.1016/0301-7516(94)90042-6

Moema, J.S., Papo, M.J., Slabbert, G.A., \& Zimba, J. (2009). Grinding media quality assurance for the comminution of gold ores. In World Gold Conference 2009 (pp. 27-34). Johannesburg, South Africa: The Southern African Institute of Mining and Metallurgy.

Moore, J.J., Perez, R., Gangopadhyay, A., \& Eggert, J.F. (1988). Factors affecting wear in tumbling mills: influence of composition and microstructure. International Journal of Mineral Processing, 22(1-4), 313-343. https://doi.org/10.1016/0301-7516(88)90071-3

Pitt, C.H., Chang, Y.M., Wadsworth, M.E., \& Kotlyar, D. (1988). Laboratory abrasion and electrochemical test methods as a means of determining mechanism and rates of corrosion and wear in ball mills. International Journal of Mineral Processing, 22(1-4), 361-380. https://doi.org/10.1016/0301-7516(88)90073-7

Radziszewski, P. (2002). Exploring total media wear. Minerals Engineering, 15(12), 1073-1087. https://doi.org/10.1016/s0892-6875(02)00228-5

Radziszewski, P. (2000). Developing an experimental procedure for charge media wear prediction. Minerals Engineering, 13(8-9), 949-961. https://doi.org/10.1016/s0892-6875(00)00080-7

Rajagopal, V., \& Iwasaki, I. (1992). The properties and performance of cast iron grinding media. Mineral Processing and Extractive Metallurgy Review, 11(1-2), 75-106. https://doi.org/10.1080/08827509208914215

Rizk, A. (1989). Study of the most important operating parameters affecting the performance of reverse closed circuit grinding. PhD Thesis. Gliwice, Poland: Silesian Technical University.

Stamboliadis, E.T. (2002). A contribution to the relationship of energy and particle size in the comminution of brittle particulate materials. Minerals Engineering, 15(10), 707-713. https://doi.org/10.1016/s0892-6875(02)00185-1

Tolfree, D. (2004). Investigation of the gouging abrasion resistance of materials in the mining industry. MSc Thesis. Vancouver, Canada: University of British Columbia.

Tolley, W.K., Nichols, I.L., \& Huiatt, J.L. (1984). Corrosion rates of grinding media in mill water. Washington, United States: Bureau of Mines Report of Investigations 8882.

U.S. DOE. (2007). Mining industry energy bandwidth study. Washington, United States: U.S. Department of Energy.

Vermeulen, L.A., Howat, D.D., \& Gough, C.L.M. (1983). Theories of ball wear and the results of a marked-ball test in ball milling. Journal of the South African Institute of Mining and Metallurgy, 189-197.

Vermeulen, L.A., \& Howat, D.D. (1986a). Abrasive and impactive wear of grinding balls in rotary mills. Journal of the Southern African Institute of Mining and Metallurgy, 86(4), 113-124.

Vermeulen, L.A., \& Howat, D.D. (1986b). The performance and wear characteristics of grinding media as affected by metallurgical and dimensional factors. Mintek Report M243. Randburg, South Africa: Mintek.

Wang, C. (2013). Comparison of HPGR-ball mill and HPGRstirred mill circuits to the existing AG/SAG mill-ball mill circuits. MSc Thesis. Vancouver, Canada: University of British Columbia. 
Weiss, N.L. (1985). SME Mineral Processing Handbook. New York, United States: Society of Mining Engineers of the American Institute of Mining, Metallurgical, and Petroleum Engineers.

Wills, B.A., \& Napier-Munn, T. (2006). Wills' mineral processing technology: an introduction to the practical aspects of ore treatment and mineral recovery. Massachusetts, United States: Elsevier Science \& Technology Books.
Yelloji Rao, M.K., \& Nararajan, K.A. (1991). Factors influencing ball wear and flotation with respect to ore grinding. Mineral Processing and Extractive Metallurgy Review, 7(3-4), 137-173. https://doi.org/10.1080/08827509108952670

\section{ОЦІНКА СТУПЕНЯ ЗНОСУ КУЛЬОВОГО МЛИНА НА ЗОЛОТОМУ РУДНИКУ МАД АД ДАХАБ (САУДІВСЬКА АРАВІЯ)}

\section{Г.С. Абделхаффез}

Мета. Оцінка ступеня зносу куль у сухого та вологому подрібнюючому середовищі в залежності від їх технологічних параметрів на прикладі кульового млина золоторудної шахти Мад Ад Дахаб (Саудівська Аравія).

Методика. Для досліджень використовувалися зразки кварцу золоторудної шахти Мад Ад Дахаб. Лабораторна щокова дробарка використовувалася для зменшення розміру зразків гірських порід до -3.15 мм, щоб бути придатними для подальшого подрібнення у кульовому млині. Дроблені зразки просіювали для отримання необхідної для параметрів лабораторного млина фракції $-3.15+2.5$ мм. Лабораторний кульовий млин із внутрішнім діаметром барабана 300 мм і його довжиною також 300 мм використовувався для досягнення вихідної фракції $(80 \%-0.074$ мм). Варіювався час подрібнення $-4,8,16,24,48,72$ і 96 годин. Знос куль розраховувався шляхом віднімання ваги куль після кожного випробування з маси початкових куль при завантаженні.

Результати. Дослідження показали, що втрата ваги куль знаходиться у прямо пропорційній залежності від ïx діаметру. Експериментально доведено, що при вологому подрібненні ступінь зносу куль на $12 \%$ менше, ніж при сухому. Встановлено, що швидкість зносу куль значно зростає зі збільшенням часу подрібнення, а коефіцієнт зносу пропорційний діаметру куль. Найбільш висока швидкість зношування куль $(0.858 \%)$ досягається при самому тривалому часі подрібнення (96 годин), найбільшому діаметрі куль (30 мм) та у сухому подрібнюючому середовищі. Визначено коефіцієнт зносу куль в технологічному циклі збагачення рудника Мад Ад Дахаб, який становить близько $1.2 \%$ в день.

Наукова новизна. Виявлено взаємозв'язок ступеня зносу подрібнюючих куль в залежності від їх діаметра і швидкості зносу від часу подрібнення зразків кварцу для кульового млина шахти Мад Ад Дахаб. Розроблено методологію оцінки ефективності процесу подрібнення в залежності від величини зносу подрібнюючого середовища.

Практична значимість. Отримані результати дозволяють оцінити загальні експлуатаційні витрати, пов'язані зі зносом кульового млина та його значним впливом на ефективність процесу подрібнення. Корегування режимів та параметрів подрібнення є основою для зниження цих витрат.

Ключові слова: прочес подрібнення, сухе і вологе подрібнююче середовище, знос, кульовий млин, рудник Мад Ад Дахаб

\section{ОЦЕНКА СТЕПЕНИ ИЗНОСА ШАРОВОЙ МЕЛЬНИЦЫ НА ЗОЛОТОМ РУДНИКЕ МАД АД ДАХАБ (САУДОВСКАЯ АРАВИЯ)}

\section{Г.С. Абделхаффез}

Цель. Оценка степени износа мелющих шаров в сухой и влажной мелющей среде в зависимости от их технологических параметров на примере шаровой мельницы золоторудной шахты Мад Ад Дахаб (Саудовская Аравия).

Методика. Для исследований использовались образцы кварца золоторудной шахты Мад Ад Дахаб. Лабораторная щековая дробилка использовалась для уменьшения размера образцов горных пород до -3.15 мм, чтобы быть пригодными для последующего измельчения в шаровой мельнице. Дробленные образцы просеивались для получения необходимой для параметров лабораторной мельницы фракции $-3.15+2.5$ мм. Лабораторная шаровая мельница с внутренним диаметром барабана 300 мм и его длиной также 300 мм использовалась для достижения выходной фракции ( $80 \%-0.074$ мм). Варьировалось время измельчения $-4,8,16,24,48$, 72 и 96 часов. Износ шаров рассчитывался путем вычитания веса шаров после каждого испытания из массы начальных шаров при загрузке.

Результаты. Исследования показали, что потеря веса шаров находится в прямо пропорциональной зависимости от их диаметра. Экспериментально доказано, что при влажном размоле степень истирания шаров на $12 \%$ меньше, чем при сухом. Установлено, что скорость износа шаров значительно возрастает по мере увеличения времени измельчения, а коэффициент износа пропорционален диаметру шаров. Наиболее высокая скорость изнашивания шаров $(0.858 \%)$ достигается при самом длительном времени измельчения (96 часов), наибольшем диаметре шаров (30 мм) и в сухой среде измельчения. Определен коэффициент износа шаров в технологическом цикле обогащения рудника Мад Ад Дахаб, который составляет порядка $1.2 \%$ в день.

Научная новизна. Выявлена взаимосвязь степени износа мелящих шаров в зависимости от их диаметра и скорости износа от времени измельчения образцов кварца для шаровой мельницы шахты Мад Ад Дахаб. Разработана методология оценки эффективности процесса измельчения в зависимости от величины износа мелющей среды. 
Практическая значимость. Полученные результаты позволяют оценить общие эксплуатационные затраты, связанные с износом шаровой мельницы и его значительным влиянием на эффективность процесса измельчения. Корректирование режимов и параметров измельчения является основой для снижения этих затрат.

Ключевые слова: процесс измельчения, сухая и влажная мелющцая среда, износ, шаровая мельница, рудник Мад Ад Дахаб

\section{ARTICLE INFO}

Received: 16 March 2018

Accepted: 3 August 2018

Available online: 10 August 2018

\section{ABOUT AUTHORS}

Gamal Sayd Abdelhaffez, Doctor of Philosophy, Associate Professor of the Mining and Metallurgical Engineering Department, University of Assiut, 71516, Assiut, Egypt. E-mail: gamalhaffez@gmail.com 